\title{
جماعة الأحباش \\ دراسة تحليلية
}

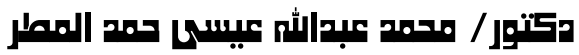

دكتور اه في العقيدة الإسلامية

المقدمة:

إن ظاهرة الافتز اق في الأمة الإسلامية التي حدثت في نهاية عهد الــصحابة وتولـدت

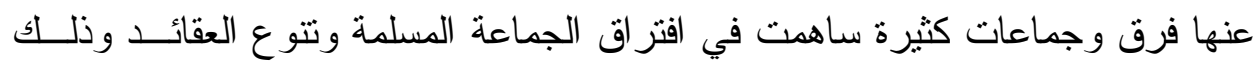

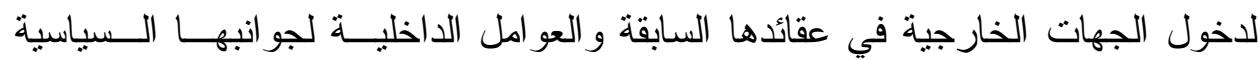
و الاقتصادية ، وقد تو اصلت أفكار الفرق الى هذا الوقت المعاصر بتأثز الجماعات بكــــل أفكار بعض الفرق او بعضها ، ومن هذه الفرق التي تأثرت بالأفكار القديمة للفرق هـئي

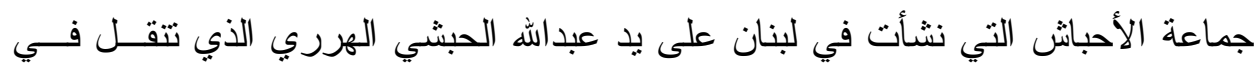

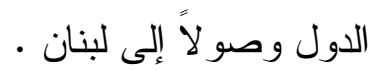
ان أفكار ومعتقدات الأحباش باتت من الظو اهر المعاصرة التي يجب تسليط الأضــــواء

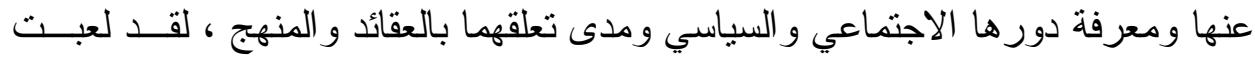

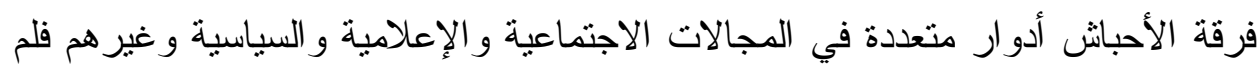

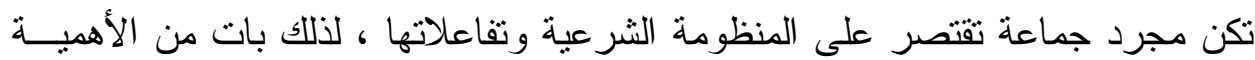

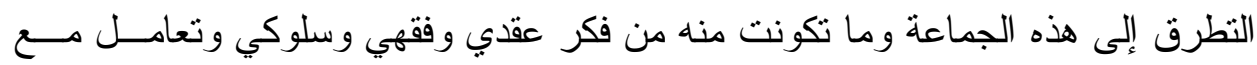

$$
\text { أهداف البحث : الآخر : ليطرف إلى البحث إلى عدة أمور منها : }
$$

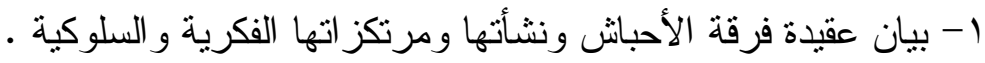

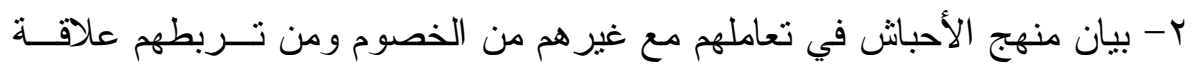

$$
\text { المودة. }
$$

r- بيان تأثير الأحباش على الواقع في لبنان وغيرها من الدول وفقاً لمنهجهم. 
تكمن أهمية البحث عن الأحباش في عدة أمور:

1- لما لهذه الفرقة من وجود في لبنان و غير ها من الدول وفاعليتها فـي الـــياق

$$
\text { الإسلامي. }
$$

r- لما لهذه الفرقة من تفاعل و اقعي ووسائل كبيرة ومؤثزة في الو اقــع الـسـياسي

$$
\text { و الاجتماعي. }
$$

r- لما لهذه الجماعة من ارتباط عقدي ببعض العقائد و الفرق ومدى الحاجـــة إلـىى

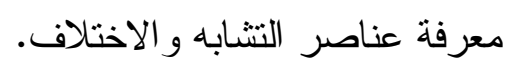

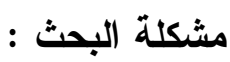

تكمن مشكلة البحث في عدة أسئلة : ا - من هم الأحباش ورموز هم ومؤسساتهم؟

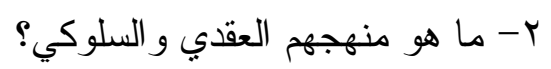

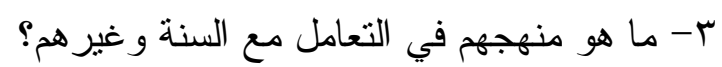
ع - ما هو أثز هم الو اقعي في تعاملهم مع الآخرين؟

الار اسات السابقة : العات

كتبت بعض الرسائل الجامعية عن موضوع الأحباش ، ومن هذه الرسائل :

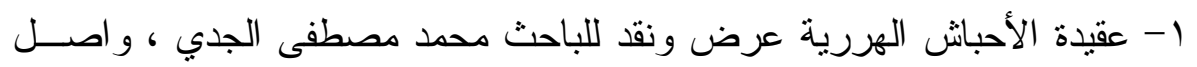

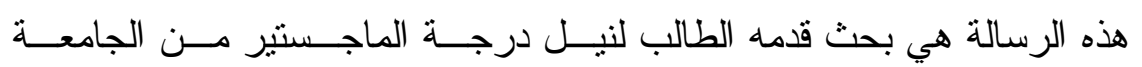
الإسلامية بغزة سنة ا ـ . بام ، وقد تتاول فيها عقيدة الأحباش ونشأتهم.

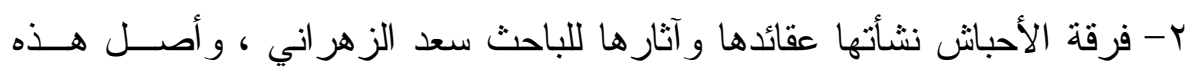

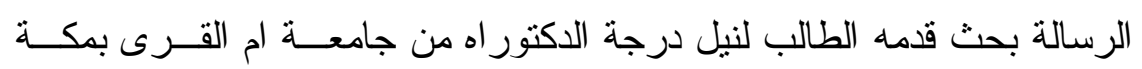
المكرمة وقد تتاول فيها الباحث عقيدة الأحباش و آثار هم ونشأتهم.

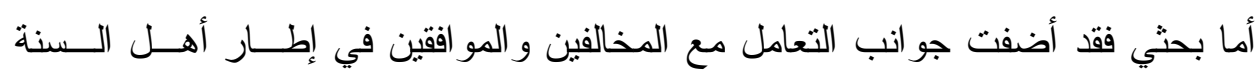
و الجماعة وغير هم من الثيعة و الاروز و النصارى وف والتعهاينة. 


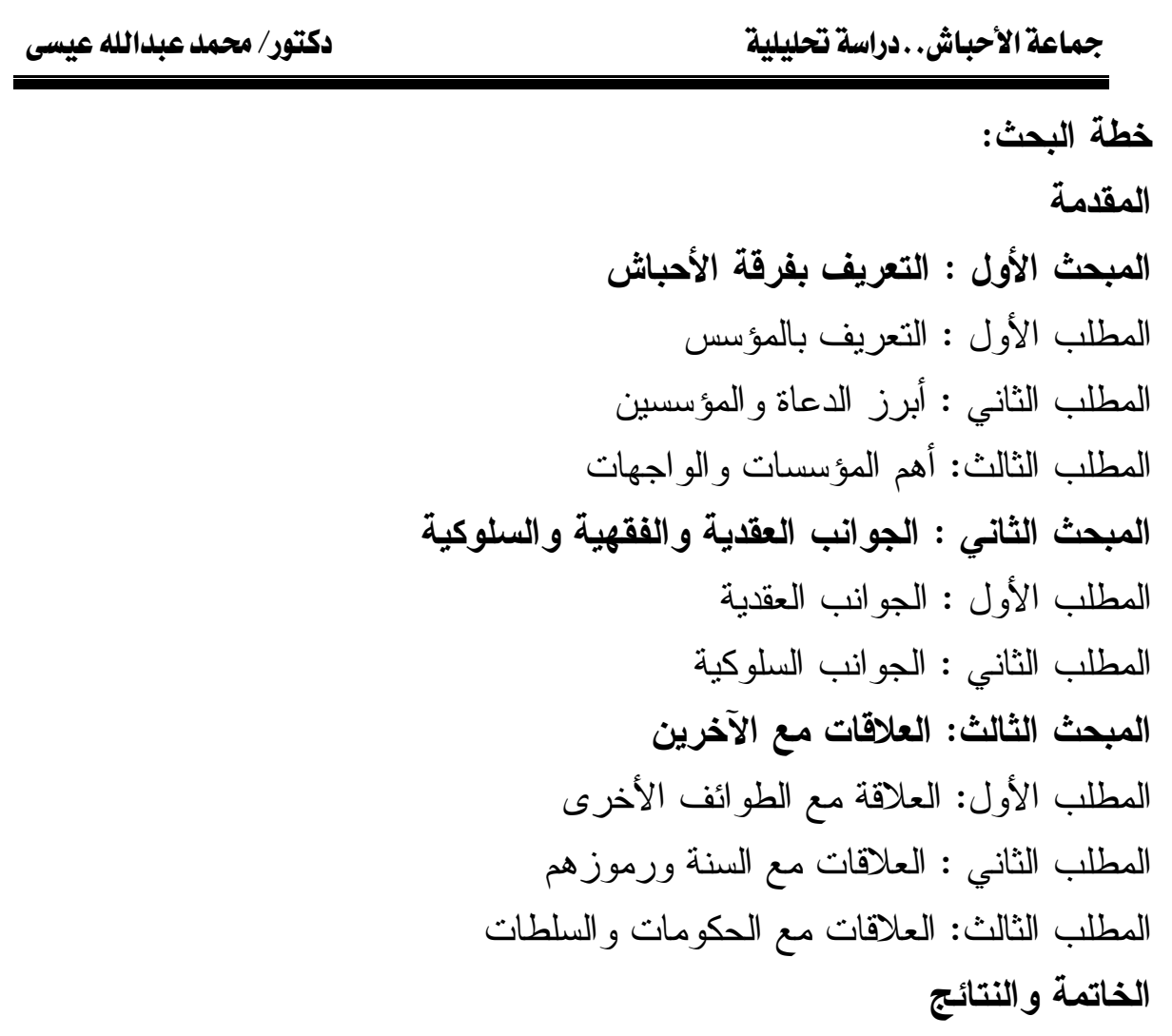




\section{المبحث الأول : التعريف بفرقة الأحباش:

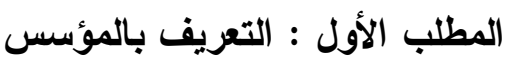 \\ أولاً: الاسم و النشأة : الأبرل}

أ- هو أبو عبد الرحمنعبد الله بن محمد الثيبي نسباً الهرري موطناً نسبة إلى مدينــة

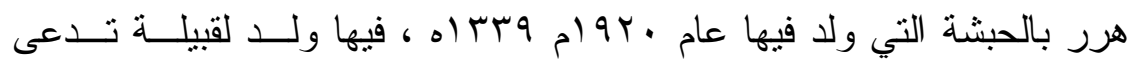

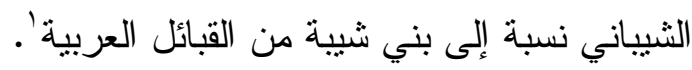

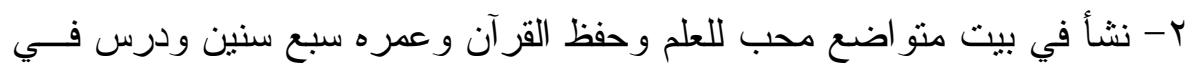

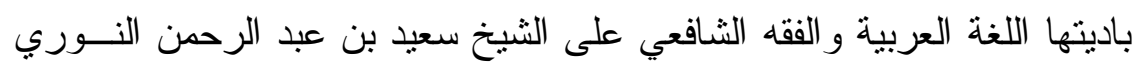

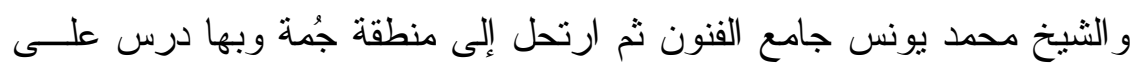

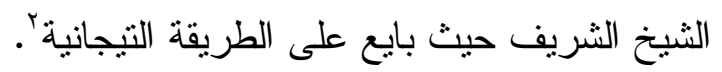

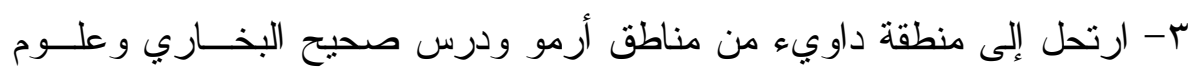

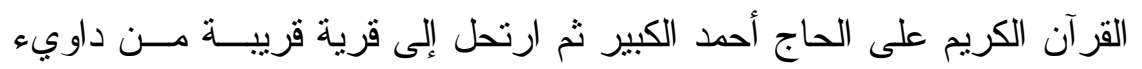

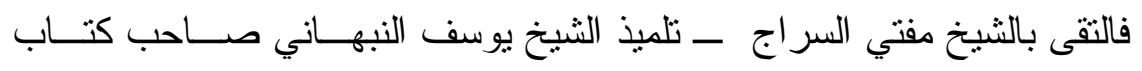

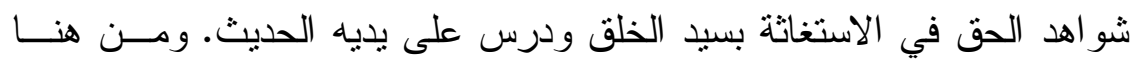

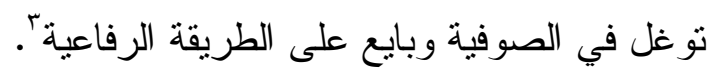

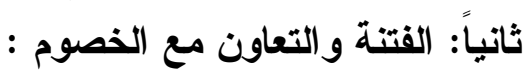

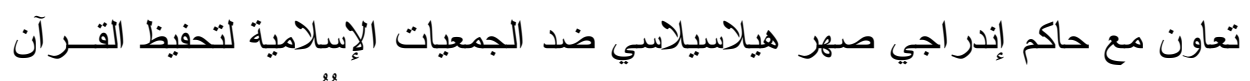

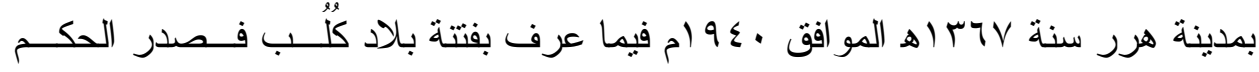

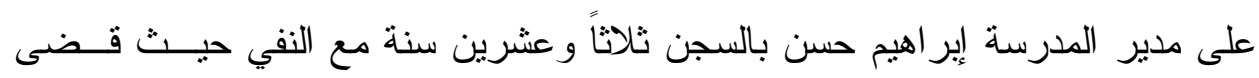

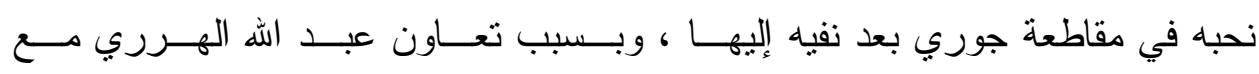

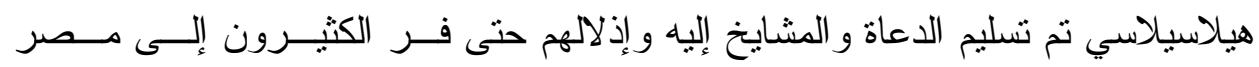
و السعودية، ويرجع سبب تعاونه ضد مدارس التحفيظ للقر آن وتعليمه بسبب أنهم ينتمون إلى (الوهابية) ، ولذلك أطلق عليه الناس هناك صفة صنة (الفتّان) أو (شيخ الفتتة)؛

\footnotetext{
'انظر : إظهار العقيدة السنية بشرح العقيدة الطحاوية - عبداله الهرري - صلالى برا

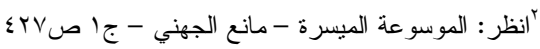

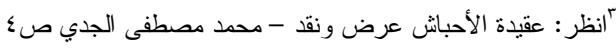

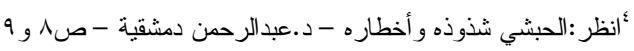


ثالثاً: الخروج من البلا :

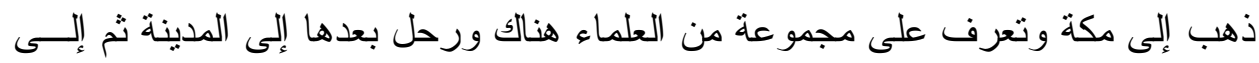

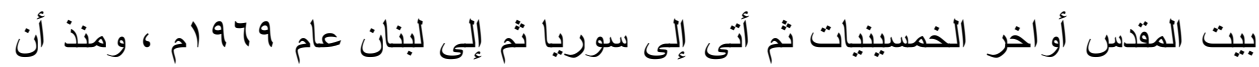

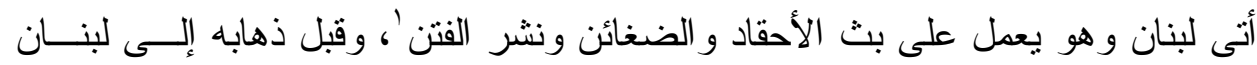

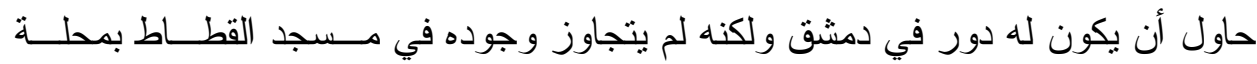

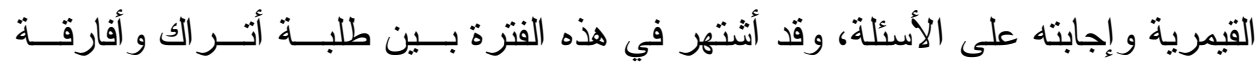

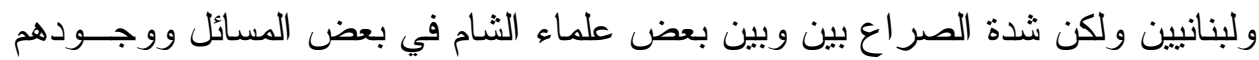
النافذ هناك ، ومع اثتداد الصر اع دعاه بعض طلبنته من لبنان إلى الهجرة إليهم في بيئة

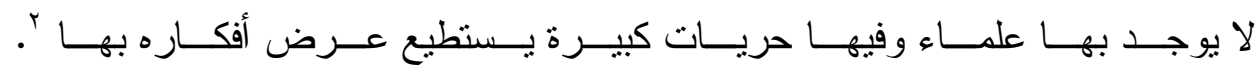
رابعاً: العمل في لبنان والاتثثار:

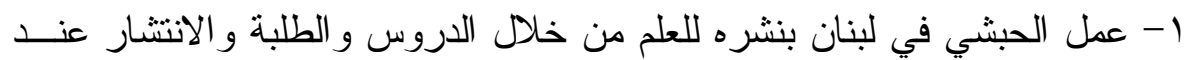

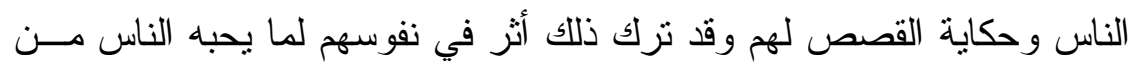

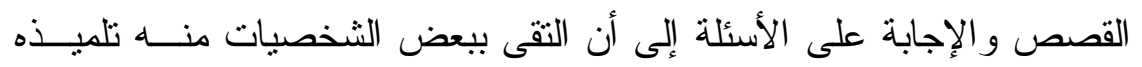
نز ار حلبي

r- في هذه المرحلة أتيح له التدريس في أزهر لبنان وتمكن من التواصل مــع دار

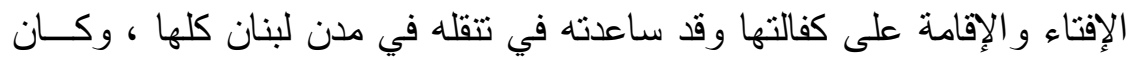

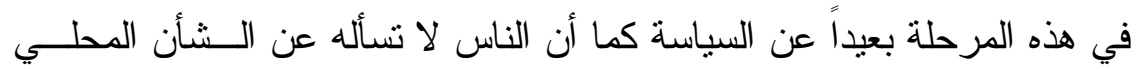
لكونه من غير أهل البلد.

r- اجتمع مع طلبته وتوجهو اللسيطرة على جمعية المشاريع الإسلامية التي كانت

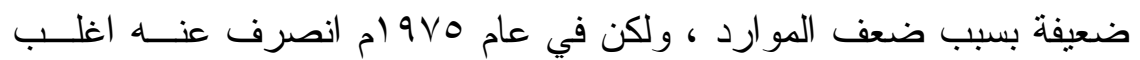

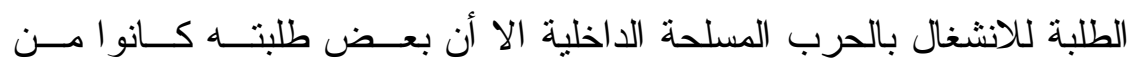

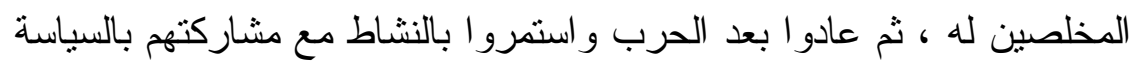
وسنأني على تفصيلها لاحقاً. 
خامساً: وفاته:

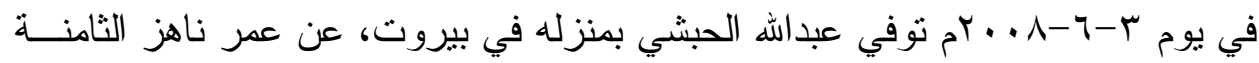

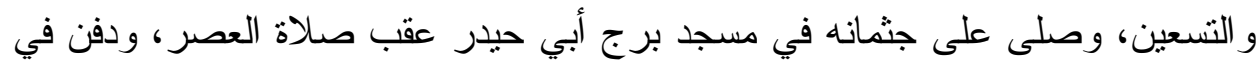

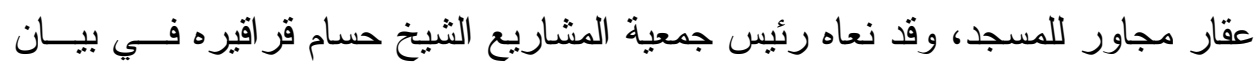

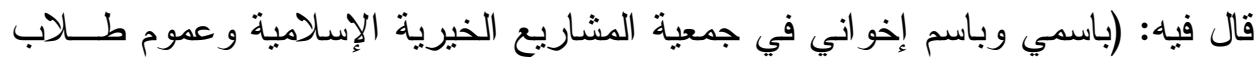

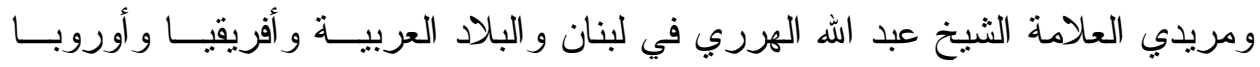
و آسيا و أستر اليا و الأمبركيتين)'

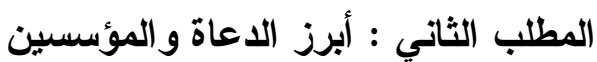

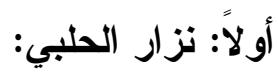

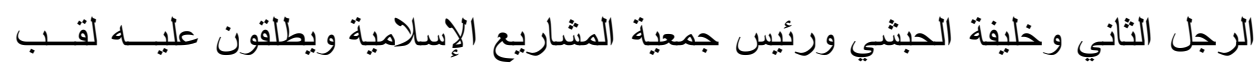

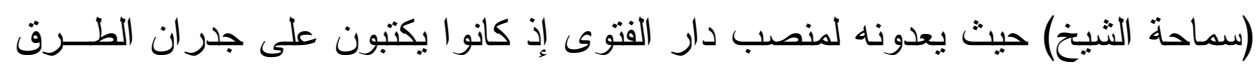

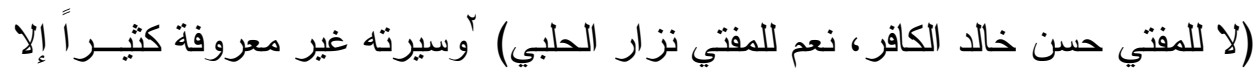

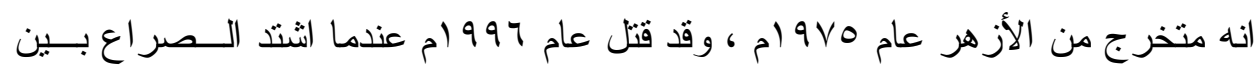

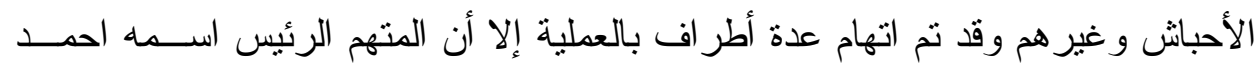

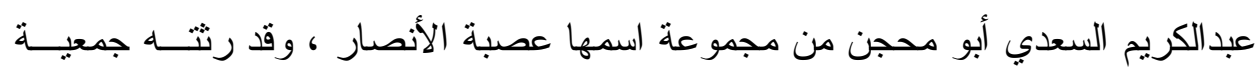

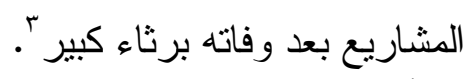

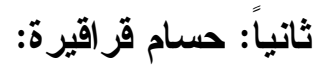

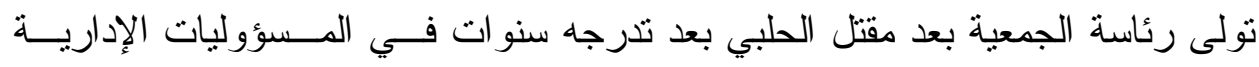

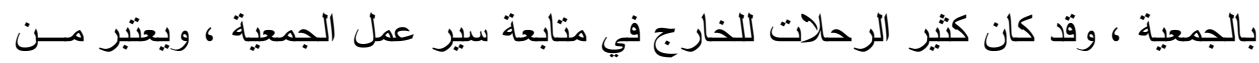

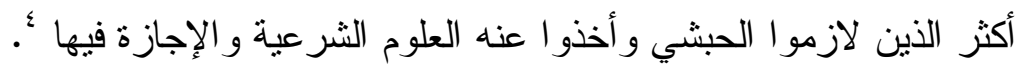

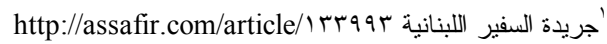

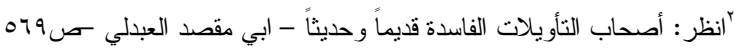

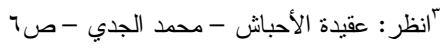
أنظر : المرجع السابق - صنال 
ثالثاً: النائب البرلماني عدنان الطر ابلسي:

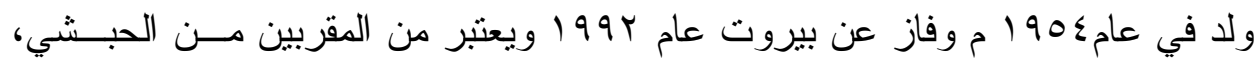

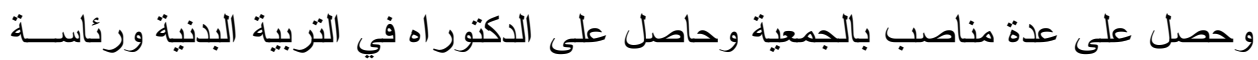

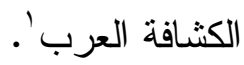

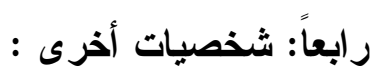

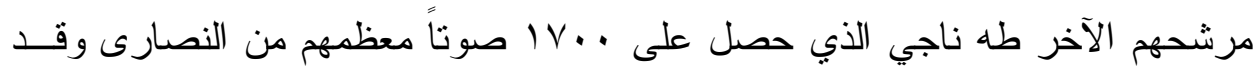

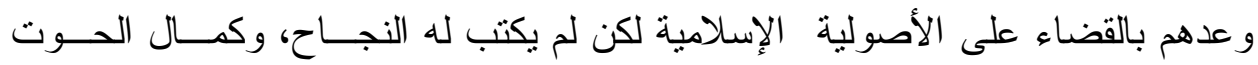

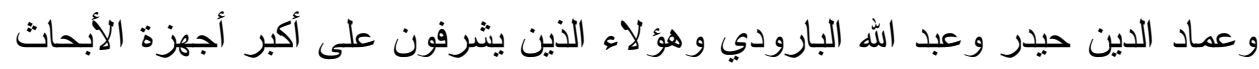

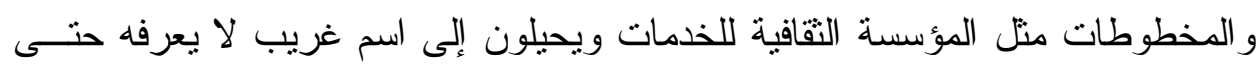

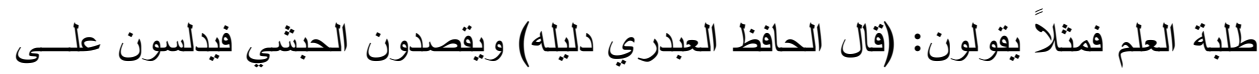

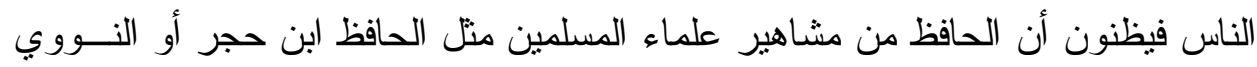
و إنما هو في الحقيقة شيخهم ينقلون من كتابه الدليل القويم مثنلاً'.

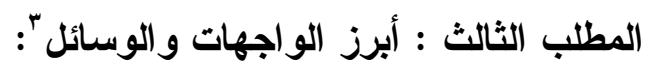
أولاً: الجمعية :

و هي جمعية المشاريع الإسلامية تشتلمو ا رئاستها عام سو ام ام وتعمل في دول مختلفــة

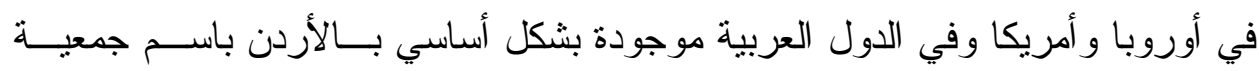

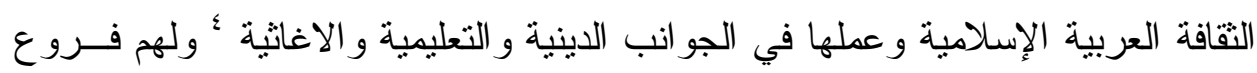
في دول أوروبية ودول مختلفة.

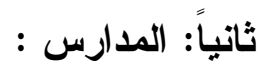

لايهم مدارس متعددة تحت اسم مدارس الثقافة ببعض مــدن لبنــان و الأردن ، وكـــللك

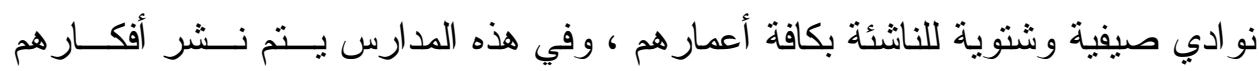

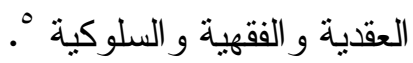

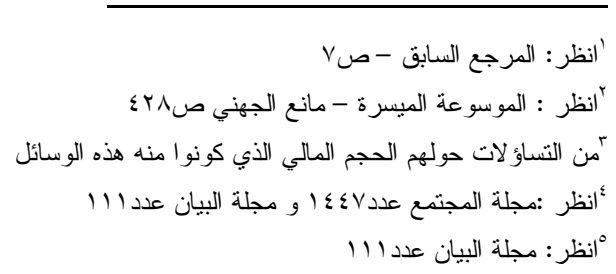




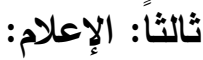

تتوعت وسائل الإعلام عند الأحباث إلى عدة وسائل منها إذاعية وتسمى نداء الإيمــان

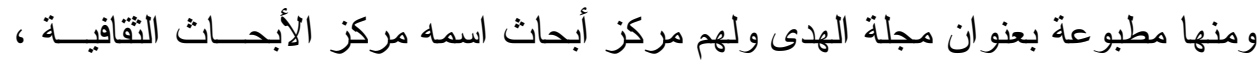

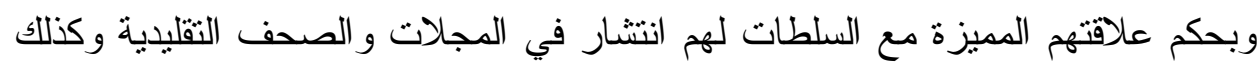
القنوات التلفزيونية في لبنان ، وفي الأردن لهم مركز أبحاث ونو اجد في قناة رؤيا'في لئي

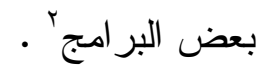

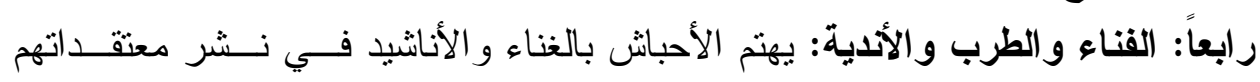

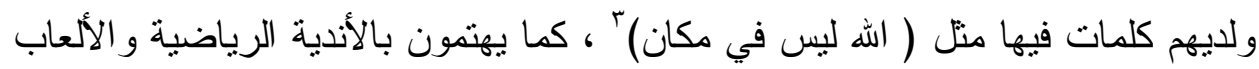

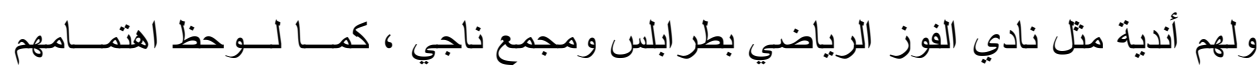

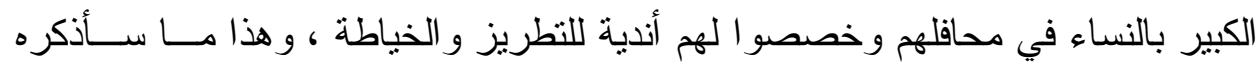
في الجانب الفقهي لاحقاً؛

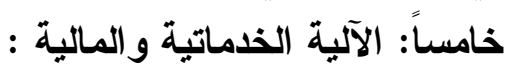
توفر الجمعية كثير من الخدمات و الدعم لكل منتسبيها خاصة وهم من الطبقة الفقيــرة او

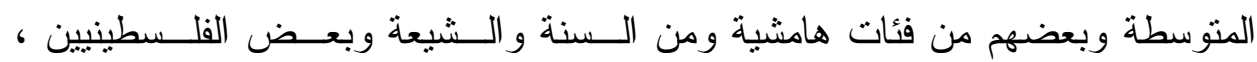

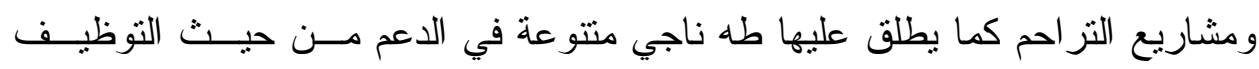
و إعطاء رأس مال للعضو فيني مشروع وصدقاته للجمعية ْ

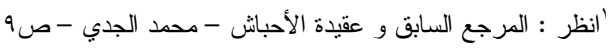

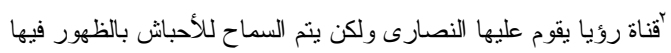

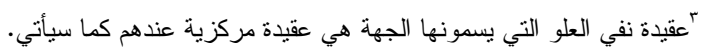

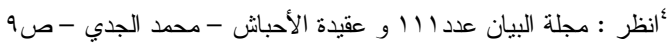

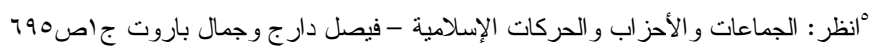




\section{المبحث الثاني : الجوانب العقدية والفقهية والسلوكية المطلب الأول : الجوانب العقدية : الجواتب البعاية}

يهتم الأحباث بالجانب العقدي اهتمام بالغ ويعطونه من الأهميـــة كثيــر أ فـــي أدبيــاتهم

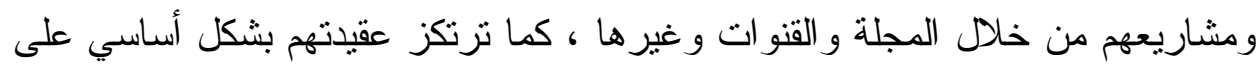

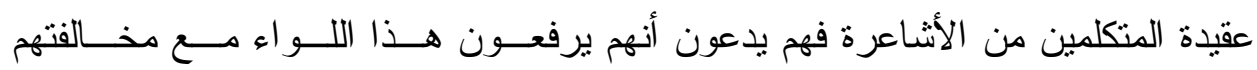

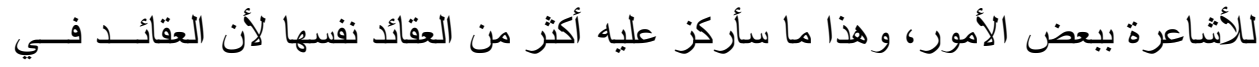

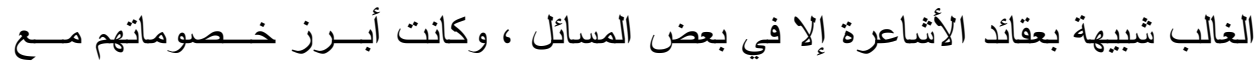

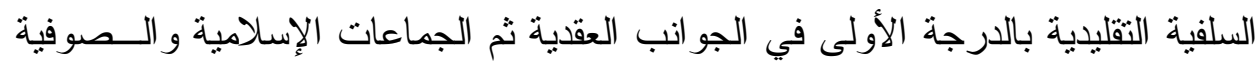

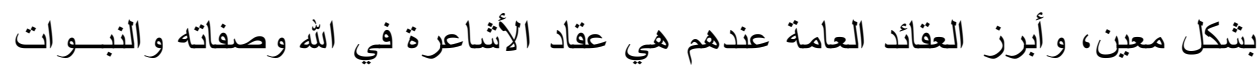

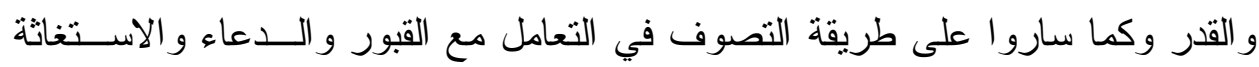
و غير ذلك ، أما العقائد المخالفة و التي جنحو الفيها فيها إلى الغلو هي :

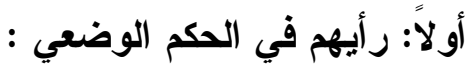

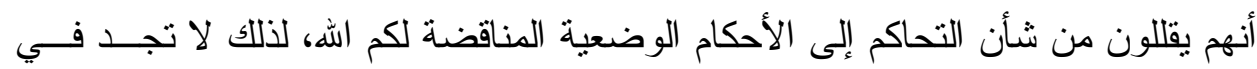

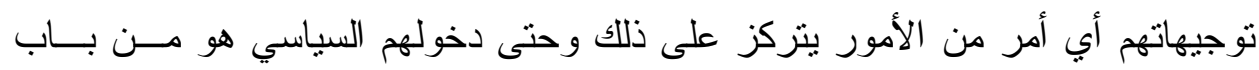

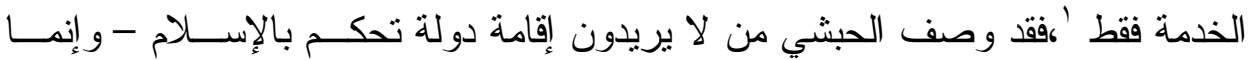

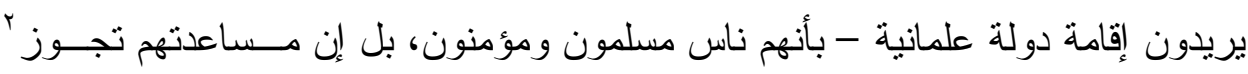

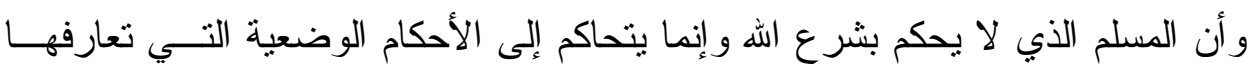

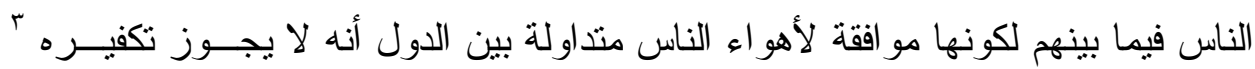

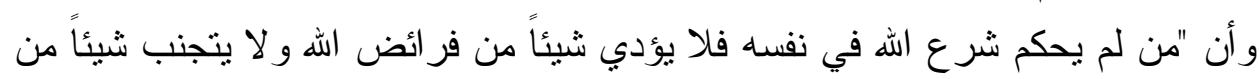

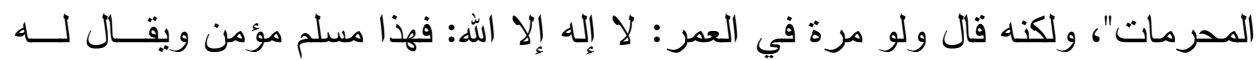

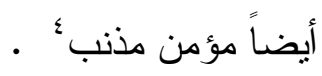
ثانياً: الموقف من الصحابة: عقيدة الأحباش في أصحاب رسول الله صلى الله عليه وسلم فيها شبه كبير مــن عقبــــة

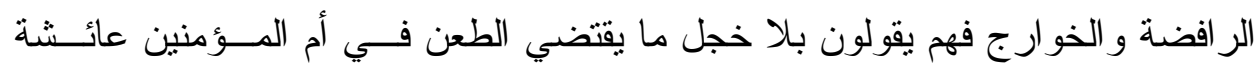

$$
\begin{aligned}
& \text { 'انظر : الجماعات و الأحز اب و الحركات الإسلامية - فيصل دارج وجمال باروت جاصهُ V. }
\end{aligned}
$$

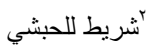

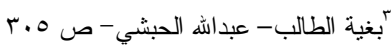

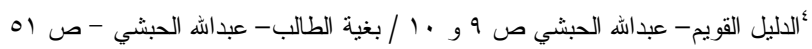


رضي الله عنها ويفسقون صاحب رسول الله صلى الله عليه وسلم وكاتب الوحي معاوية

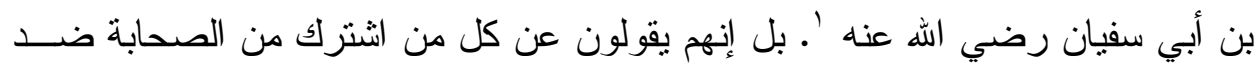

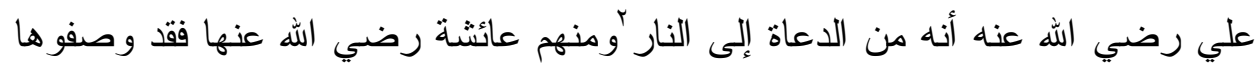

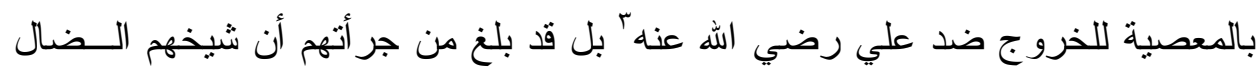

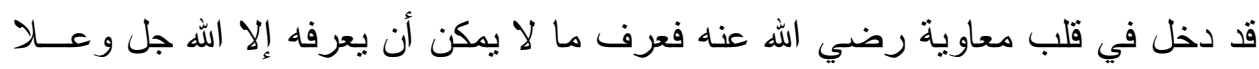

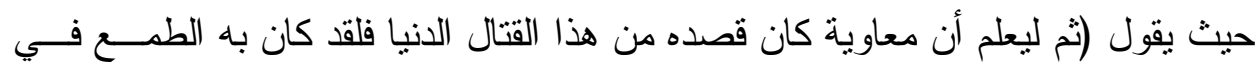
الملك وفرط الغر ام في الرئاسة)؛ ثالثاً: التكفير:

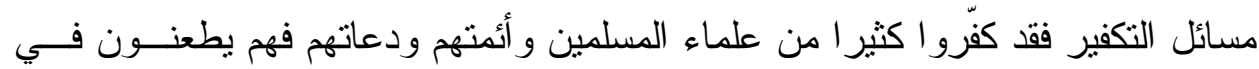

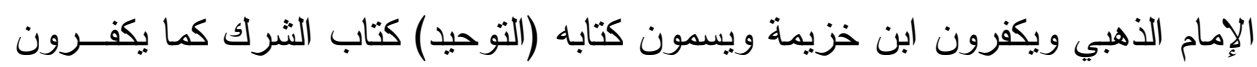

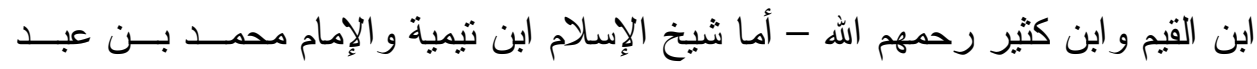
الوهاب فتكفير هما على لسان كل حبشي صباح مساء ولم يسلم أعلام الأمة المعاصرون

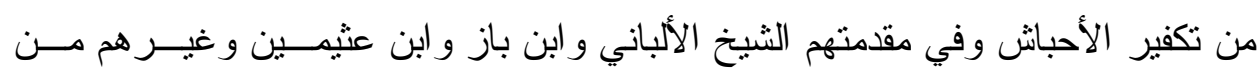
العلماء و الدعاء و المفكرين.

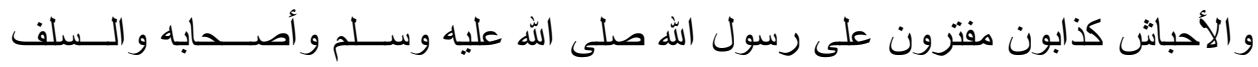

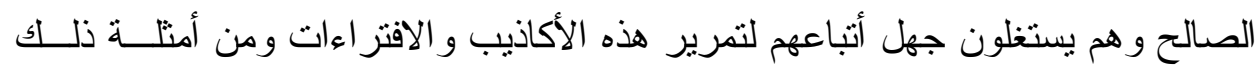

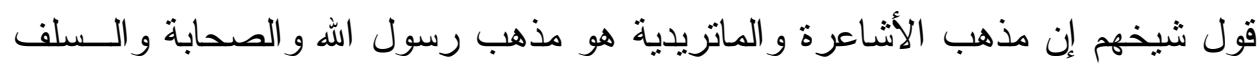

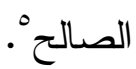
أما افتر اؤهم على الأئمة و العلماء فحدث و لا حرج وخاصة على شيخ الإسلام ابن تيمية

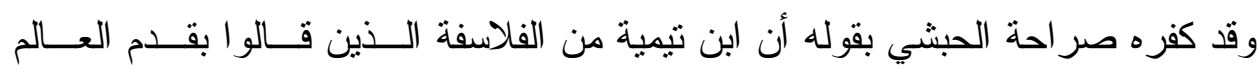

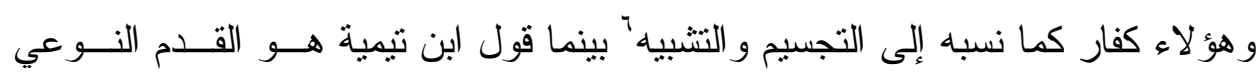

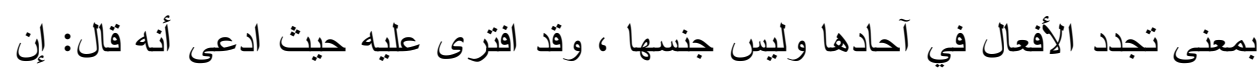

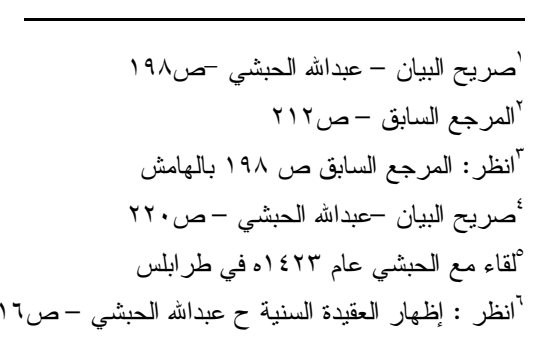


من خالف في مسألة الطلاق فهو كافر '، ولكن ابن تيمية يقول (إن من خالف في مسألة

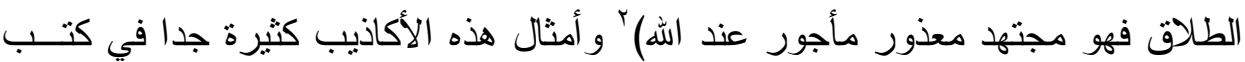

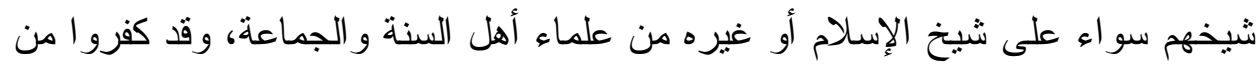

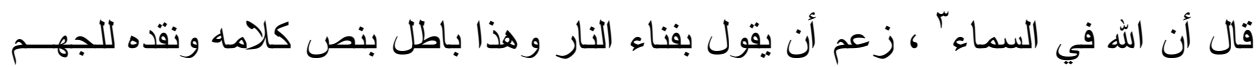

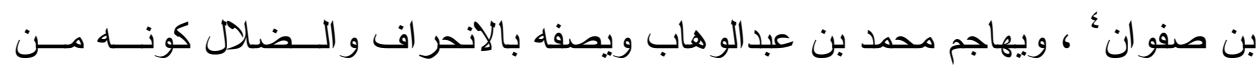

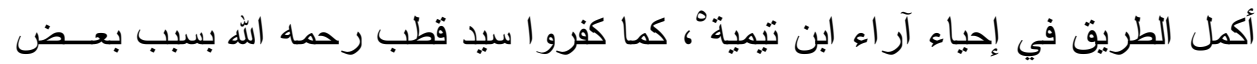

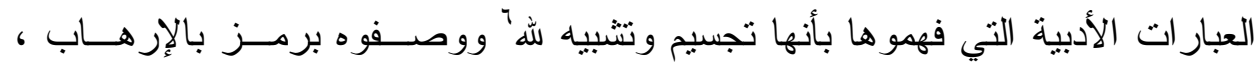

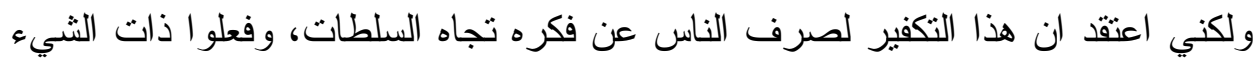
مع المودودي و القرضاوي و غير هم ، ولهم تشدد كبير في سب و الطعن في محمد ناصر

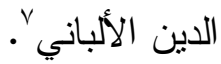

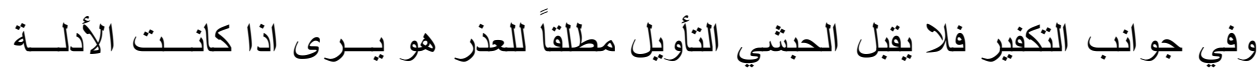

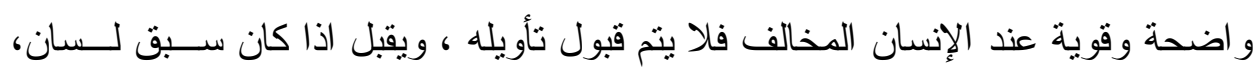

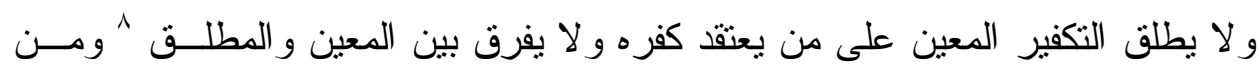

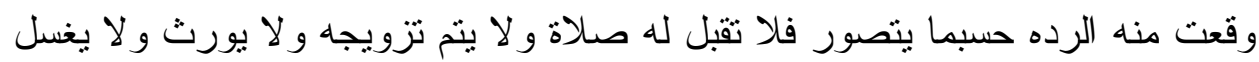

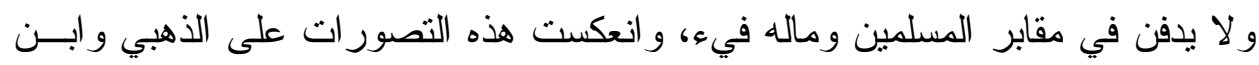
حجر وسيد قطب و القرضاوي من المعاصرين في التكفير و التضليل. رابعاً: عقيدتهم إجمالاً:

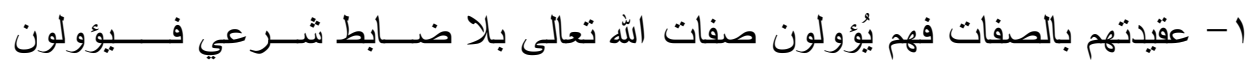

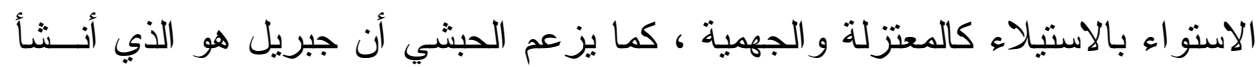

$$
\begin{aligned}
& \text { 'انظر : المقالات السنية - عبداله الحبثي - }
\end{aligned}
$$

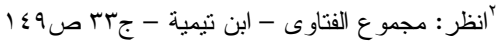

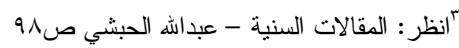

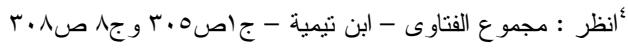

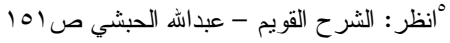

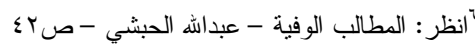

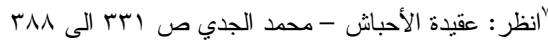

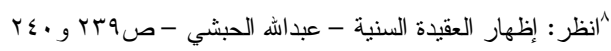


ألفاظ القرآن الكريم وليس اله تعالى، فالقر آن عنده ليس بكلام اله تعــالى، و إنمــا هـــ عبارة عن كلام جبريل، كما في كتابه' r- مسألة الإيمان من المرجئة الجهمية الذين يؤخرون العمل عن الإيمان ويبقى الرجل

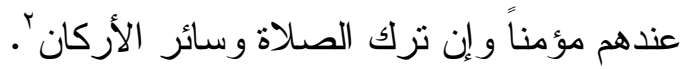

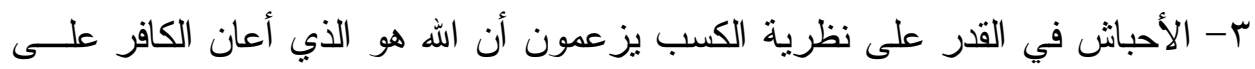

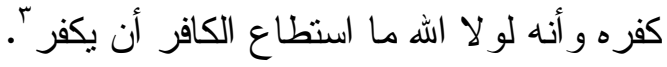
ع- يحث الأحباش الناس على التوجه إلى قبور الأموات و الاستغاثة بهم وطلب قـ فـاء

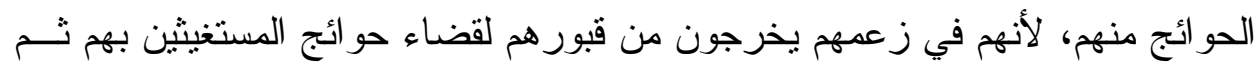

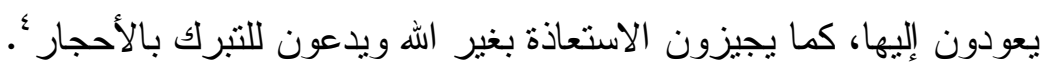

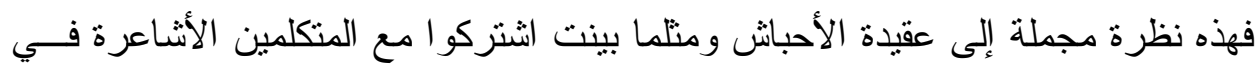
كثير من قضايا الاعتقاد و الطريقة الكلامية في تتاول مجالات العقائد ولكنهم اختلفو الفي قضايا بينتها تتعلق بالصحابة و التكفير و غير هما. المطلب الثاني: الجوانب السلوكية

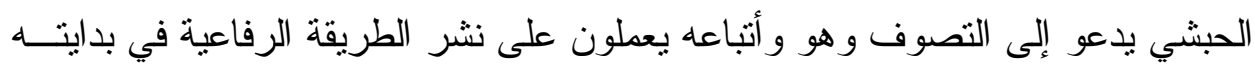

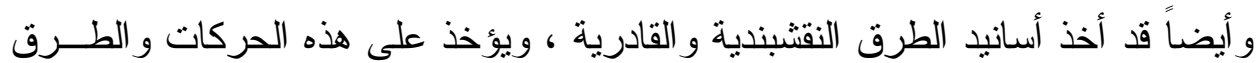

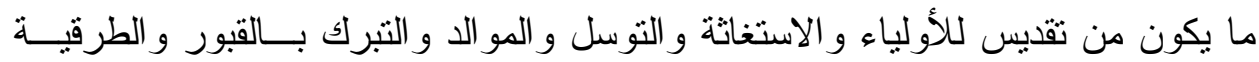

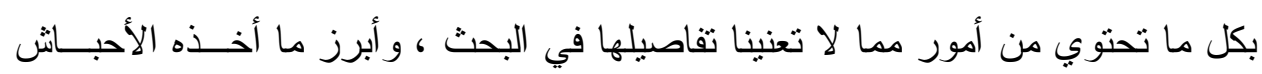

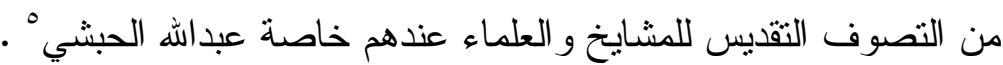

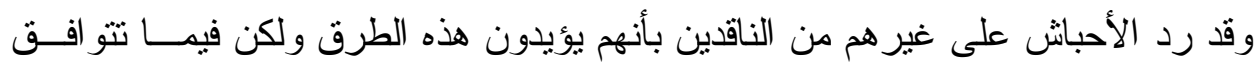

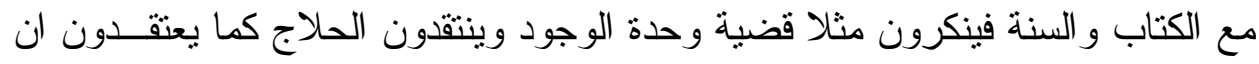

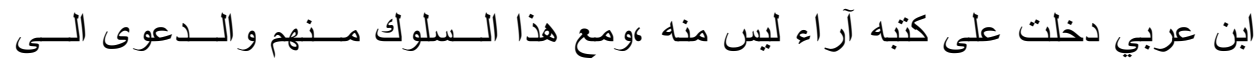
التصوف حصلت صدامات كبيرة منهم مع الطرق منها جماعة الثيخ رجــب و الـشيخ

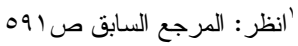

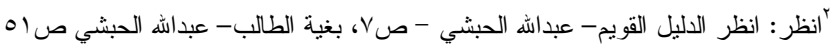

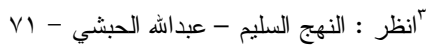

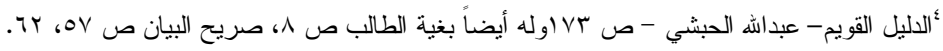

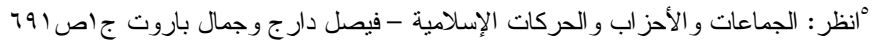




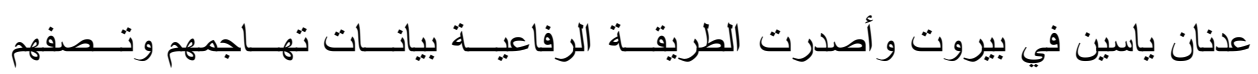

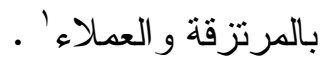
كما ينقل بعض خصومهم تعلقهم بالمشعوذين وحضور مجالسهم مع اســتعمال بعـــهم

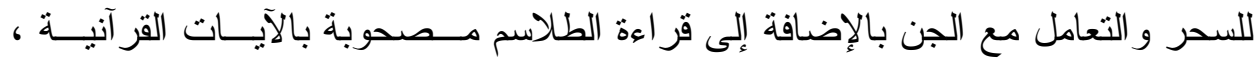
ويبقى الجانب الصوفي عند الأحباش من أكثر الجوانب التي فيها الصدامات مع التيــار

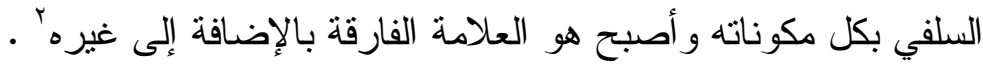


المبحث الثالث: العلاقات مع الآخرين المطلب الأول: العلاقة مع الطوائف الأخرى تعتبر العلاقة مع الطوائف و الأحز اب خارج السياق السني علامة تعجب عند من من يتــابع

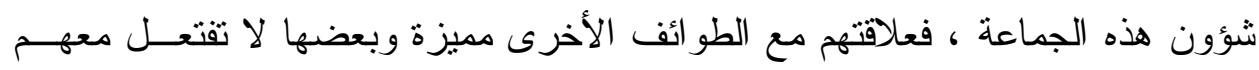

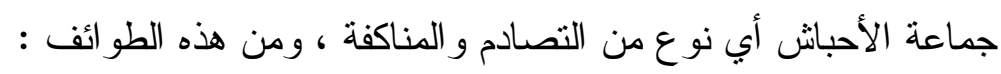

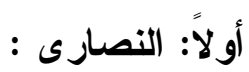

فيحاول الأحباش كثثراً في لبنان على إيجاد صيخ التفاهم و الحوار معهم وعدم التـصـادم

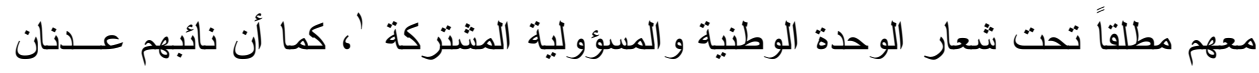

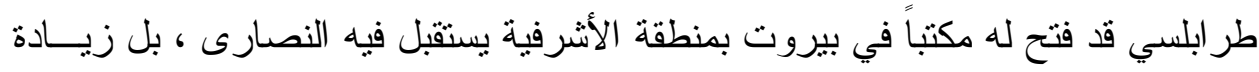

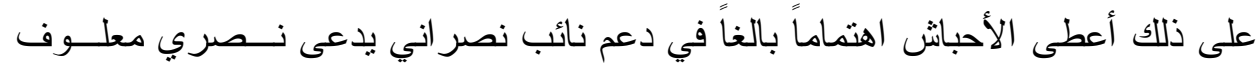

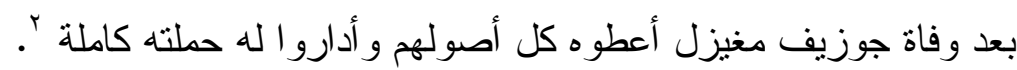
ثانياً: الشيعة : باة جوزئ

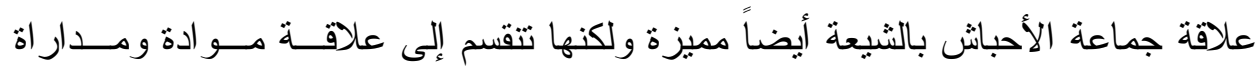

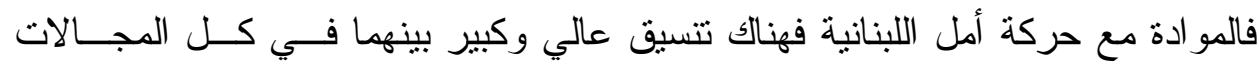

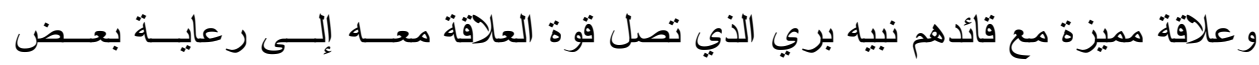

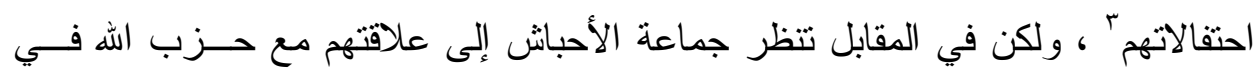

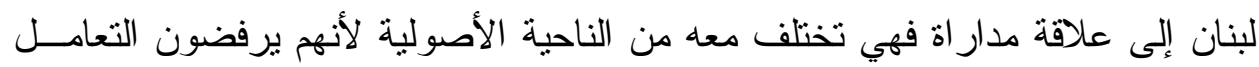

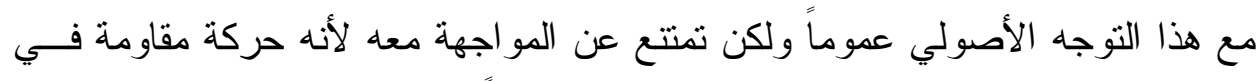

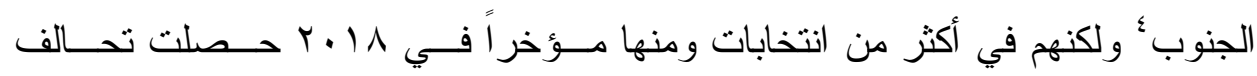

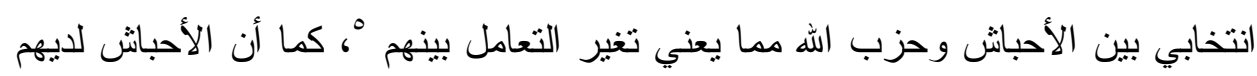

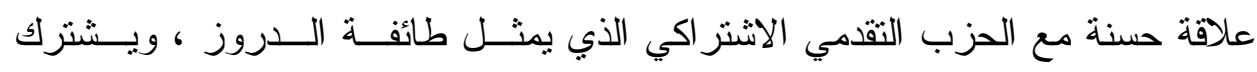

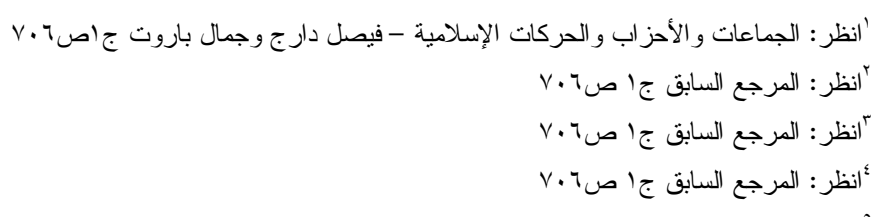

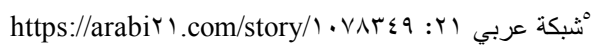


الأحباش مع الثيعة في بغض الصحابة معاوية رض الله عنه و الطعن و التــليل فـي

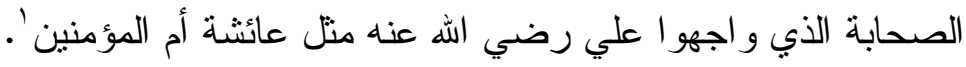
ثالثاً: الصهاينة :

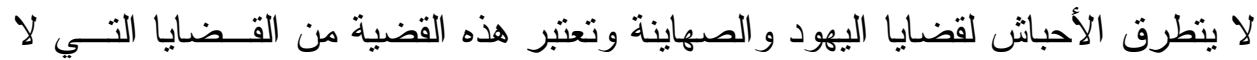

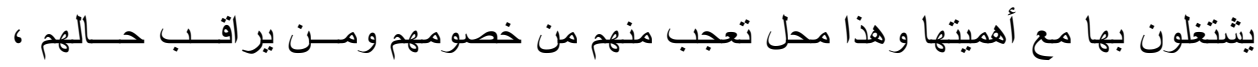

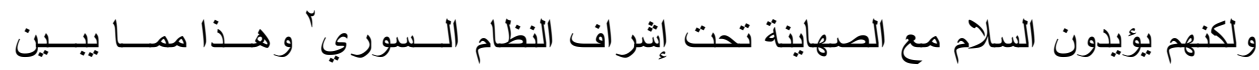
علاقتهم معه التي سأبينها لاحقاً.

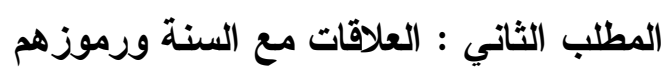

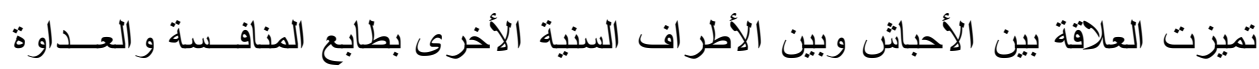

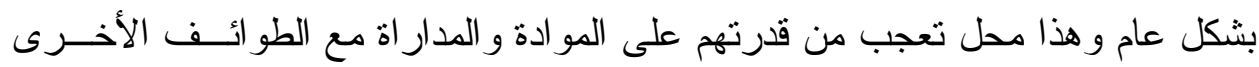

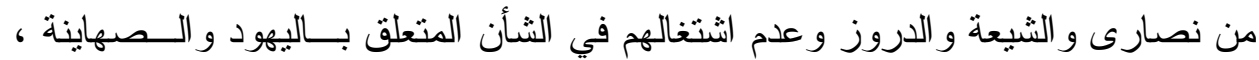

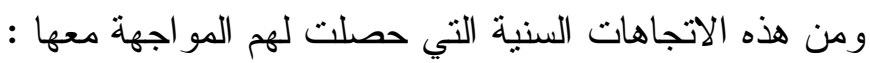
أولاً: دار الإفتاء: هذه الآتاهات

بدأت العلاقة بين جماعة الأحباش وشيخهم الحبشي مع دار الإفتاء بالعلاقة الجيدة حيث

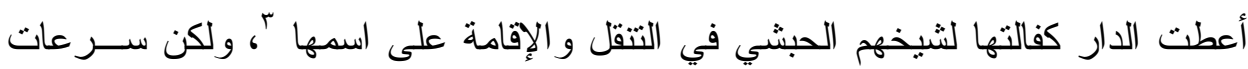

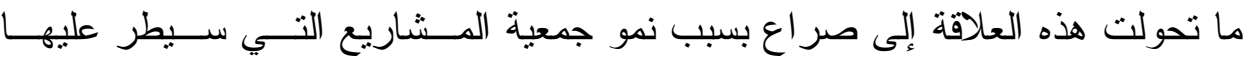

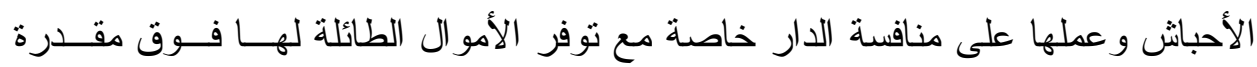
الدار ، كما أن هنالك اعتر اضات شكلية ساهمت في تدهور العلاقة بسبب نظرة الأحباش

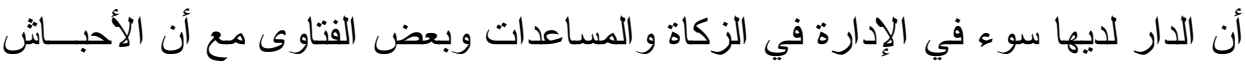

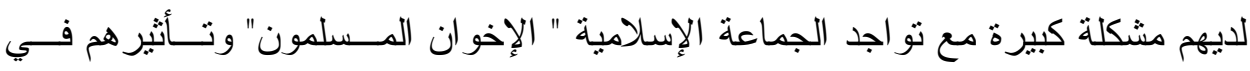

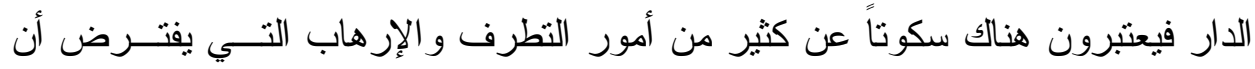

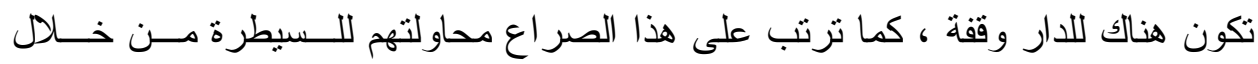

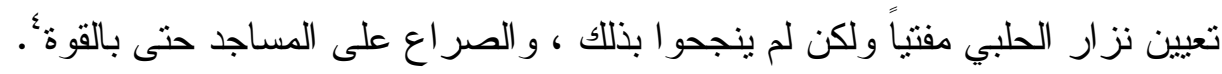

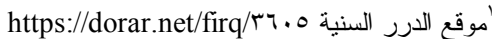

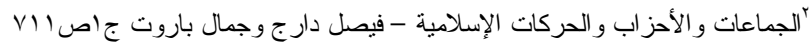

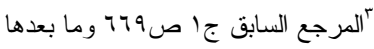

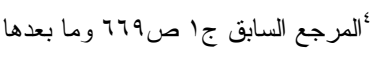


ثانياً: الجماعة الإسلامية (الإخوان المسلمون - لبنان):

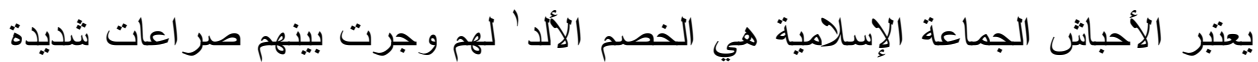

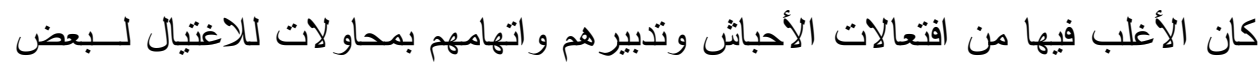

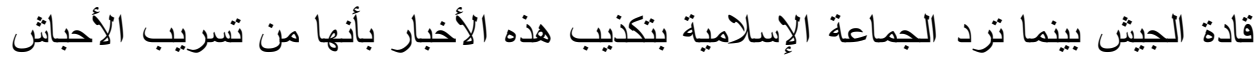

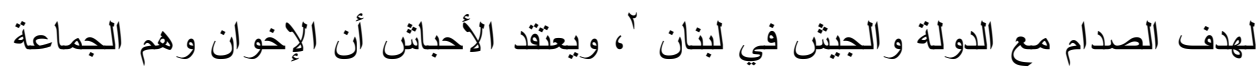

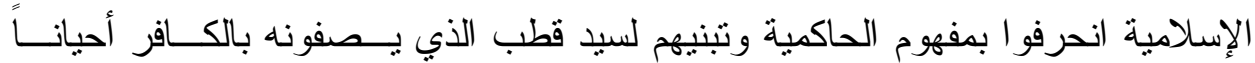

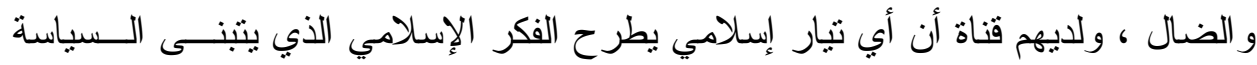

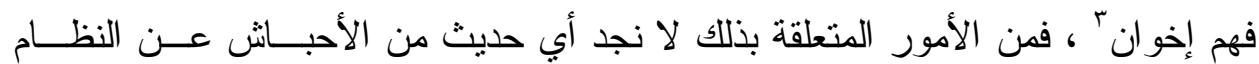

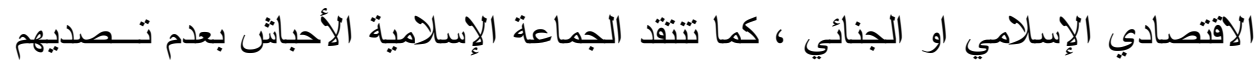
لقضايا اليهود و الصهاينة وتحريمهم القتال لليهود في الجنوب كما يرون.

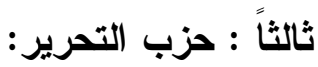

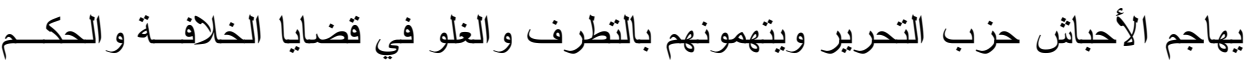

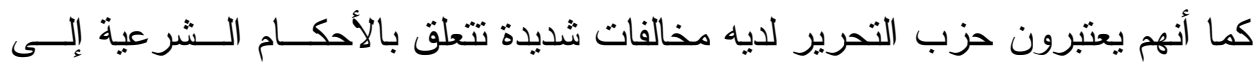

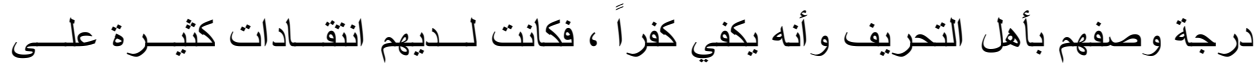

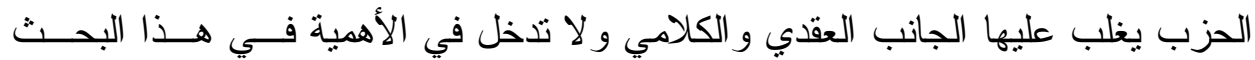

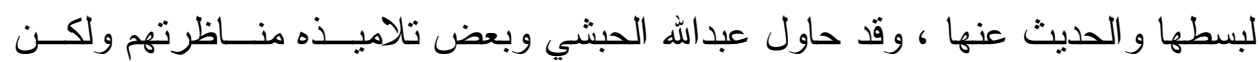

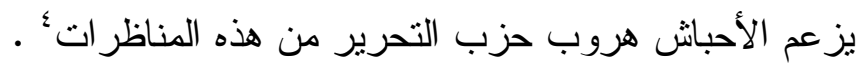

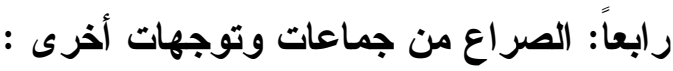

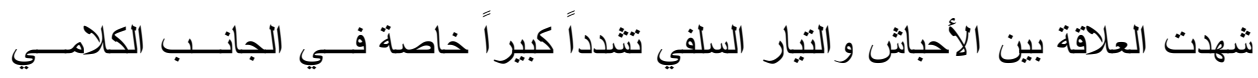

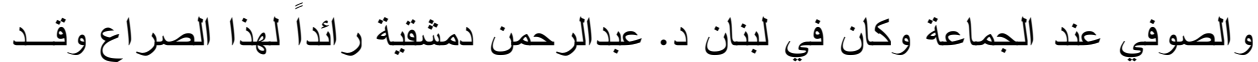

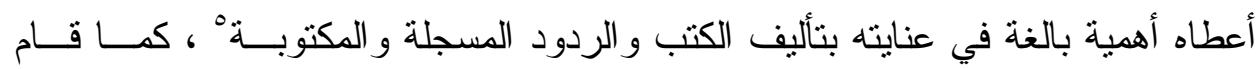

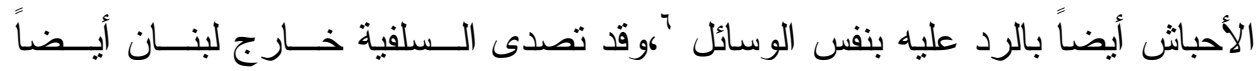


للأحباش بالردود و المساجلات' ، و لا تختلف هذه العداوات مع غير هم منل جماعة عباد الرحمن وحركة التوحيد الني يقودها الثيخ سعيد شعبان الذي ينظر أن السلطة في لبنان

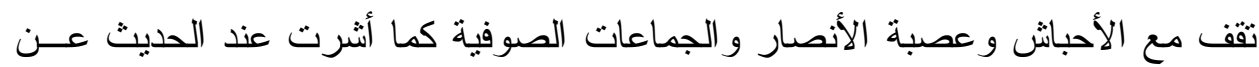

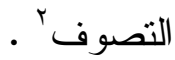


خرجت هذه الدر اسة عن موضوع الأحباش بعدة نتائج ومنها: ا- أن عبداله الحبشي الهرري شخصية ولات في الحبشة وتلقت العلوم الـشرعية هناك وكذلك الطريقة الصوفية و المعتقد الأشعري و المذهب الثافعي في الققه .

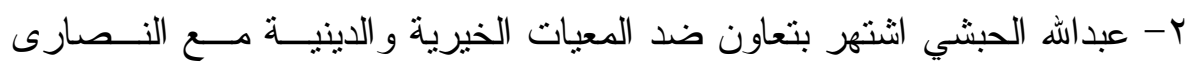
بسبب أن هذه الجمعيات مرجعيتها سلفية أو و هابية.

r- عبداله الحبشي انتقل إلى عدة دول وصل به التتقل إلى دمثنق التي جلس فئهـيـا.

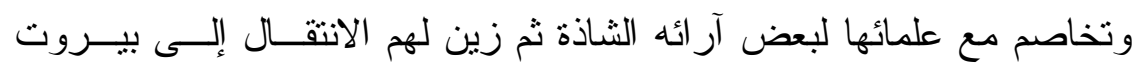
فاستقر هنالك بوجود بيئة محدودة العلماء.

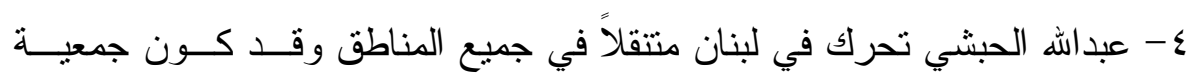

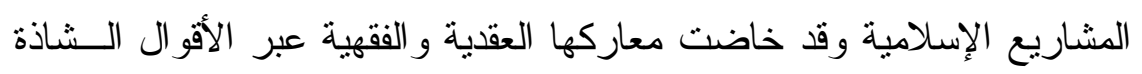

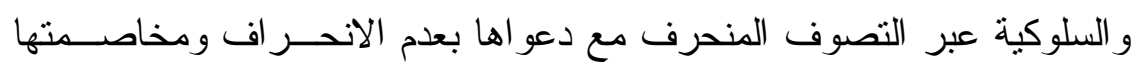

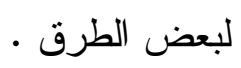

0- كانت جماعة الأحباش لها علاقات مودة مع الطو ائف المختلفة مع أهل الــسنة

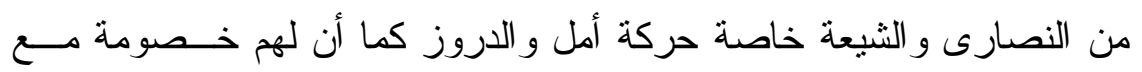
طو ائف السنة من الإخوان المسلمين وحزب التحرير و التيار السلفي وغيرهم.

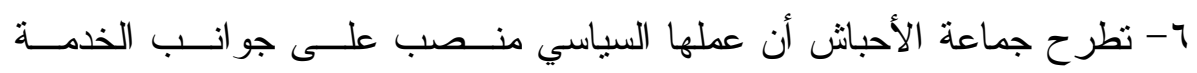

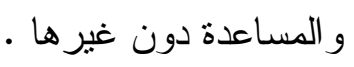




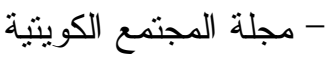
- مجلة البيان السعودية

- عقيدة الأحباش - محمد مصطفى الجدي-بحث تكميلي لنيل درجة الماجستير في العقيــدة

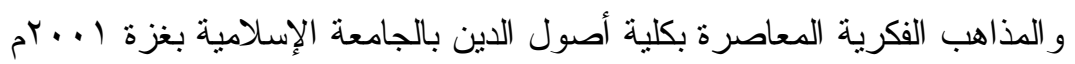

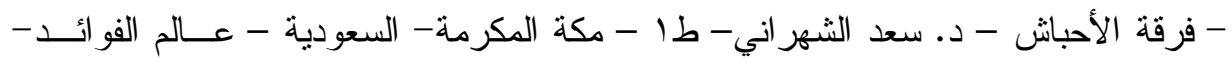
(هب

- الجماعات و الحركات و الأحز اب الإسلامية - فيصل دارج وجمال باروت- طا - بيروت

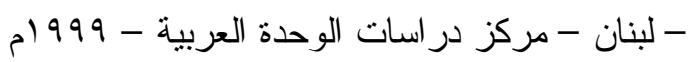
ــ المقالات السنية في كثف ضدلالات ابن تيمية، عبد اله الحبشي -بيروت - لبنـان - دار المشاريع ع 99 ام.

ـ التعقيب الحثيث عبد الله الحبشي بيروت - لبنان - دار المشاريع -.

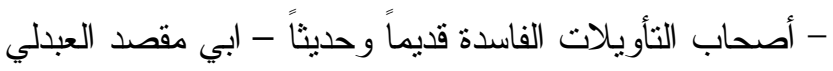

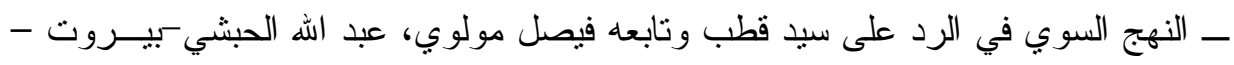
لبنان - دار المشاريع.

ــ الدليل القويم على الصر اط المستقيم، عبد اله الحبشي -بيروت - لبنان - دار المشاريع.

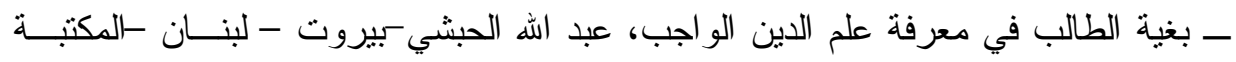

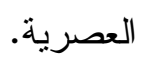

ــ إظهار العقيدة السنية شرح العقيدة الطحاوية، عبد اله الحبشي كيــروت - لبنــان - دار

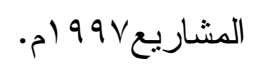
ـ كتاب المولد النبوي، عبد اله الحبشي -بيروت - لبنان - دار المشاريع.

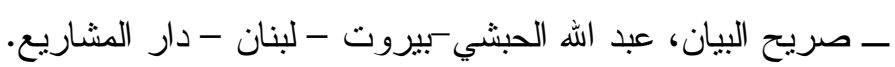

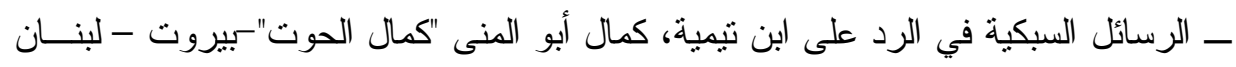

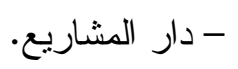

ــ التوفيق الرباني في الرد على ابن تيمية الحر اني، كمال أبو المنى "كمال الحوت"سيــروت

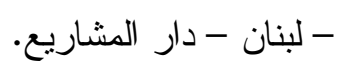
- بهجة النظر، عبد اله الحبشي -بيروت - لبنان - دار المشاريع. 


$$
\begin{aligned}
& \text { ـ مجلة منار الهذى } \\
& \text { ـ الرد على الثيخ الحبثي ــ الثيخ عنمان الصافي. } \\
& \text { ـ استو اء الله على العرش - أسامة القصاص. }
\end{aligned}
$$

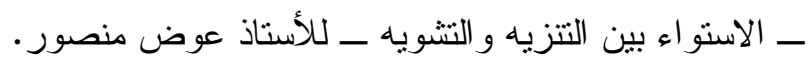

$$
\begin{aligned}
& \text { - إطلاقة الأعنَّة رسالة منسوبة للشيخ الهانشمي. }
\end{aligned}
$$

ــ رسالة الرد على الحبشي في موضوع إعانة الكـافرين علــى كفــرهم عـــنان ياســين النقشبندي.

- ع عبد الله الحبشي: عقائده وشذوذه، عبد الرحمن دمشقية. ـ الرد على عبد الله الحبشي، عبد الرحمن دمثقية. - بين أهل السنة وأهل الفنتة، عبد الرحمن دمثقية. ــ شبهات أهل الفتتة وأجوبة أهل السنة، عبد الرحمن دمشقية مخطوط ومسجل على شـــريط كاسيت.

ــ الأضو اء الساطعة على ما في كتاب (الدليل على الصر اط المستقيم) مــن أفكــار زائفـــة

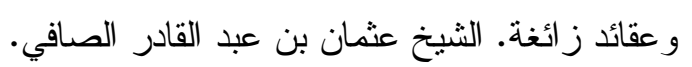
ــ مجلة الفرقان الكويتية. ـ مجلة الثر اع اللبنانية في حوار مع عدنهان الطنان الطر ابلسي نائب البرلمان. ـ الرد على الأحباش الثيخ محمد ناصر الدين الألباني شريط كاسيت. 